\title{
UJI KEASLIAN MADU LEBAH HUTAN APIS DORSATA DARI NEKTAR UNIFLORA ACACIA MANGIUM MENGGUNAKAN SPEKTROSKOPI ULTRAVIOLET DAN KEMOMETRIKA
}

\section{Authentication of Monofloral Apis dorsata Honey from Acacia mangium Using UV Spectroscopy and Chemometrics}

\author{
Diding Suhandy ${ }^{1 *}$, Meinilwita Yulia ${ }^{2}$ \\ ${ }^{1}$ Jurusan Teknik Pertanian - Fakultas Pertanian -Universitas Lampung \\ Jl. Prof. Dr. Sumantri Brojonegoro No. 1 Bandar Lampung, 35145 \\ ${ }^{2}$ Program Studi Mekanisasi Pertanian - Jurusan Teknologi Pertanian -Politeknik Negeri Lampung \\ Jl. Soekarno-Hatta No.10, Rajabasa, Bandar Lampung, Lampung Indonesia, 35141 \\ *Penulis Korespondensi, email: diding.sughandy@fp.unila.ac.id
}

Disubmit: 1 Januari 2021 Direvisi: 20 Februari 2021 Diterima: 16 April 2021

\begin{abstract}
ABSTRAK
Produksi madu uniflora cukup terbatas, khususnya yang dihasilkan oleh lebah hutan Apis dorsata. Madu uniflora yang dihasilkan lebah hutan Apis dorsata dari nektar bunga pohon Akasia Mangium (Acacia mangium) merupakan salah satu madu hutan premium yang sangat populer di Indonesia dan Malaysia. Studi uji keaslian madu uniflora Acacia mangium menggunakan spektroskopi ultraviolet belum dilakukan. Penelitian ini dilakukan untuk mengevaluasi penggunaan spektroskopi ultraviolet dan kemometrika untuk membedakan madu uniflora Acacia mangium dengan madu multiflora yang memiliki warna mirip madu uniflora Acacia mangium. Sebanyak 50 sampel madu uniflora Acacia mangium dan 50 sampel madu multiflora disiapkan sebagai sampel. Sampel tersebut disiapkan dengan cara mencampurkan madu dan air distilasi dengan perbandingan 1:30 (volume/volume). Spektra seluruh sampel madu dan referensi (air distilasi) di panjang gelombang 190-1100 $\mathrm{nm}$ (full spectrum) diakuisisi menggunakan spektrometer UV-visible (Genesys $^{\mathrm{TM}} 10 \mathrm{~S}$ UV-Vis, Thermo Scientific, USA). Klasifikasi tidak terbimbing menggunakan metode HCA dan PCA menunjukkan sampel madu dapat dikelompokkan ke dalam dua kluster berbeda yaitu kluster madu uniflora dan kluster madu multiflora. Klasifikasi terbimbing menggunakan metode LDA menunjukkan hasil yang sangat memuaskan dengan nilai akurasi sebesar $100 \%$ berhasil diperoleh baik untuk kalibrasi maupun prediksi
\end{abstract}

Kata kunci : Akurasi Klasifikasi; LDA; Madu Acacia Mangium; Pemalsuan Madu; Uji Keaslian

\section{ABSTRACT}

The production of monofloral honey is quite limited, especially that produced by Apis dorsata forest honeybees. The monofloral honey produced by Apis dorsata bees from the flower nectar of the Acacia mangium tree (Acacia mangium) is one of the premium forest honey which is very popular in Indonesia and Malaysia. The study of the authenticity of Acacia mangium monofloral honey using UV spectroscopy has not been carried out. This research was conducted to evaluate the use of UV spectroscopy and chemometrics to discriminate monofloral Acacia mangium honey from multifloral honey which has a similar color to Acacia mangium monofloral honey. A total of 50 samples of Acacia mangium monofloral honey and 50 samples of multifloral honey were prepared as samples. The sample was prepared by mixing honey sample and distilled water in a ratio of 1:30 (volume / volume). Spectra of all honey and reference samples (distilled water) at 190-1100 $n m$ (full spectrum) wavelengths were acquired using a UV-visible spectrometer (Genesys TM $10 S$ UV-Vis, Thermo Scientific, USA). Unsupervised classification using the HCA and PCA methods indicated that the honey samples could be grouped into two different clusters, namely the monofloral honey cluster and the multifloral honey cluster. Supervised classification using the LDA method shows very satisfying results with an accuracy value of $100 \%$ successfully obtained for both calibration and prediction 


\section{PENDAHULUAN}

Menurut SNI (standar nasional Indonesia), yang dimaksud dengan madu adalah cairan alami yang umumnya mempunyai rasa manis yang dihasilkan oleh lebah madu dari sari bunga tanaman (floral nektar) atau bagian lain dari tanaman (ekstra floral nektar) atau ekskresi serangga. Menurut standar internasional seperti Codex Alimentarius (Revised Codex Standard for Honey Codex STAN 12-1981, Rev. 1 (1987), Rev. 2. 2001), madu didefinisikan sebagai bahan pemanis alami yang diproduksi oleh lebah madu dari nektar tanaman atau dari sekresi bagian hidup tanaman atau ekskresi serangga penghisap tanaman, kemudian lebah mengumpulkan dan mengubahnya dengan menggabungkan dengan zat spesifik yang mereka miliki, mengumpulkan, mengeringkan, menyimpan dan meninggalkannya di sarang lebah sampai matang (Da Silva et al., 2016). Definisi yang lebih umum untuk madu adalah bahan pemanis alami yang dihasilkan oleh lebah madu dari nektar bunga (Lenhardt et al., 2014). Komposisi utama madu adalah gula (glukosa, fruktosa, maltose, dan sukrosa) dan air. Komponen pendukung lainnya dari madu adalah protein, asam amino, vitamin, mineral, senyawa fenolik, senyawa volatil dan lipid (Da Silva et al., 2016; Tewari dan Irudayaraj, 2004). Selain dimanfaatkan sebagai sumber pangan bernutrisi tinggi, madu juga telah dikenal lama sebagai salah satu sumber pangan dengan manfaat medis tinggi (Kuropatnicki et al., 2018).

Secara umum berdasarkan jenis nektarnya madu dapat diklasifikasikan menjadi dua yaitu madu uniflora dan madu multiflora. Sebuah madu diklasifikasikan sebagai madu uniflora jika mengandung hanya satu nektar bunga. Hanya saja, pada kenyataannya sangat sulit untuk mendapatkan madu uniflora yang secara absolut hanya terdiri atas satu nektar bunga. Atas dasar itu maka biasanya batasan madu uniflora yang digunakan adalah adanya nektar bunga yang dominan dengan nilai ambang batas (threshold) yang berbeda-beda untuk setiap madu (Kasprzyk et al., 2018). Misalnya untuk madu uniflora akasia dan bunga matahari dapat dikategorikan sebagai madu uniflora jika mengandung nektar akasia dan bunga matahari minimal 20\% dan 40\% (Lenhardt et al., 2014). Meskipun demikian, secara umum ambang batas untuk madu uniflora adalah mengandung nektar bunga dominan sebesar 45\% (Mehretie et al., 2018).

Produksi madu uniflora cukup terbatas khususnya yang dihasilkan oleh lebah hutan Apis dorsata. Dengan produksi yang terbatas ini sebagian besar madu uniflora diperdagangkan dengan harga lebih mahal dibandingkan dengan madu multiflora (Andrade et al., 1999). Meskipun masih diperdebatkan, sebagian besar madu uniflora dipercaya memiliki kelebihan dari aspek organoleptik dan farmakologi (manfaat medis) dibandingkan madu multiflora (Martins et al., 2008). Hal ini mendorong terjadinya pemalsuan madu uniflora oleh madu multiflora terutama yang memiliki kemiripan warna. Pemalsuan bisa dalam bentuk pencampuran madu uniflora dan multiflora (adulteration) atau pemberian label madu uniflora untuk madu multiflora (mislabeling).

Saat ini kebutuhan untuk melakukan uji keaslian madu uniflora tengah berkembang dengan sangat pesat sebagai salah satu konsekuensi tingginya permintaan madu uniflora sebagai salah satu madu yang digunakan dalam pengobatan herbal (natural remedy) (Kasprzyk et al., 2018). Metode yang selama ini digunakan untuk mengevaluasi kualitas madu dan identifikasi jenis madu untuk menentukan keaslian madu uniflora adalah menggunakan tiga metode tradisional yaitu berdasarkan uji fisik dan kimia (physicochemical method), uji nektar (pollen analysis) dan uji sensorik (sensory analysis) (Oddo dan Piro, 2004; Piana et al., 2004; Von Der Ohe et al., 2004). Pengujian fisik dan kimia biasanya menggunakan beberapa parameter berikut sebagai basis analisis: warna, viskositas, konduktivitas listrik, kadar air, aktivitas air, kandungan padatan terlarut, hydroxymethylfurfural (HMF), komposisi gula, total keasaman, total abu, asam amino, dan protein (Anjos et al., 2015; Mădaş et al., 2019; Mondragón-Cortez et al., 2013). Ketiga jenis metode tradisional tersebut memiliki beberapa kelemahan yaitu analisis bersifat merusak sampel (destructive), lama waktu analisisnya (time-consuming), mahal biaya analisisnya, melibatkan proses persiapan sampel yang banyak dan melelahkan serta membutuhkan keahlian khusus untuk bisa menjalankan analisisnya (Lenhardt et al., 2014).

Identifikasi madu uniflora dan multiflora menggunakan analisis berbasis sifat optik (spectroscopic method) telah dilakukan dengan menggunakan rentang panjang 
gelombang yang berbeda dari mulai near infrared, mid infrared, hingga terahertz (Hennessy et al., 2010; Kasprzyk et al., 2018; Liu et al., 2018), termasuk Raman spectroscopy (Corvucci et al., 2015), fluorescence spectrosocpy (Mehretie et al., 2018), dan NMR (nuclear magnetic resonance) spectroscopy (Kuballa et al., 2018). Sebagian metode analisis berbasis optik tersebut memiliki beberapa kelebihan seperti bersifat tidak merusak (nondestructive), cepat analisisnya, dan sedikit proses persiapan sampelnya serta mudah dalam menjalankan prosesnya. Hanya saja sebagian besar metode analisis tersebut masih melibatkan instrumen yang mahal sehingga sulit untuk proses hilirisasinya.

Salah satu metode analisis berbasis optik yang potensial untuk dikembangkan dengan harga instrumen yang lebih terjangkau adalah spektroskopi ultraviolet. Metode ini memiliki beberapa kelebihan lain seperti mudah dalam pengoperasiannya, persiapan sampel yang bebas bahan kimia (non-toxic) juga pengukuran spektra yang cukup cepat. Potensi spektroskopi ultraviolet untuk identifikasi kualitas madu di Indonesia sudah dimulai dilakukan seperti klasifikasi madu berdasarkan jenis lebah (Apis dorsata versus Apis mellifera) dengan ketepatan klasifikasi sebesar 100\% berhasil diperoleh menggunakan metode SIMCA (Suhandy et al., 2020).

Madu uniflora yang dihasilkan lebah Apis dorsata dari nektar bunga pohon Mangium (Acacia mangium) merupakan salah satu madu hutan premium yang sangat populer di Indonesia dan Malaysia. Secara umum madu uniflora Acacia mangium memiliki warna yang terang dan memiliki potensi zat antioksidan yang tinggi (Moniruzzaman et al., 2013) dengan komponen utama yaitu senyawa glukosa (sekitar $30 \mathrm{~g} / 100 \mathrm{ml}$ ), fruktosa (sekitar $44 \mathrm{~g} / 100 \mathrm{ml}$ ), dan air (sekitar 22\%) (Liu et al., 2018). Sampai saat ini dari hasil penelurusan pustaka, studi uji keaslian madu uniflora Acacia mangium menggunakan spektroskopi ultraviolet belum dilakukan. Pada penelitian ini dilakukan evaluasi penggunaan spektroskopi ultraviolet dan kemometrika untuk membedakan madu uniflora Acacia mangium dengan madu multiflora yang memiliki warna mirip madu uniflora Acacia mangium.

\section{METODE}

\section{Sampel Madu}

Sampel madu uniflora dan multiflora diperoleh dari dua peternak lebah madu yang berbeda di provinsi Lampung. Madu uniflora Apis dorsata dari nektar bunga Acacia mangium diperoleh dari peternakan lebah madu Suhita Bandar Lampung dalam bentuk botol kemasan dengan berat 385 g. Sampel madu multiflora Apis dorsata diperoleh dari peternakan lebah madu Kelompok Tani Hutan (KTH) An-Nahl Dusun Rejosari RT 3, RW 3, Desa Pematang Pasir Kecamatan Ketapang Kabupaten Lampung Selatan dalam bentuk botol kemasan dengan berat 1000 g. Kedua jenis madu merupakan hasil panen tahun 2020.

\section{Persiapan Sampel Madu}

Seluruh sampel madu dikirim dengan kemasan plastik dan dijauhkan dari sinar matahari langsung. Sampel dibawa ke laboratorium Rekayasa Bioproses dan Pasca Panen (RBPP), Jurusan Teknik Pertanian Universitas Lampung pada hari yang sama. Sampel kemudian disimpan dalam lemari pendingin dengan suhu sekitar $20-25{ }^{\circ} \mathrm{C}$. Sesuai dengan prosedur yang dilakukan oleh Frausto-Reyes et al. (2017), sebelum digunakan sebagai sampel, madu terlebih dahulu mendapatkan perlakuan panas secara tidak langsung menggunakan water batch bersuhu $60{ }^{\circ} \mathrm{C}$ selama 30 menit untuk menghilangkan kristalisasi pada madu. Pada penelitian ini sebanyak 50 sampel madu uniflora Acacia mangium dan 50 sampel madu multiflora disiapkan sebagai sampel. Sampel disiapkan dengan cara mencampurkan madu dan air distilasi dengan perbandingan 1:30 (volume/volume). Untuk memastikan campuran homogen, sampel madu diaduk dengan pengaduk magnetik selama 10 menit dengan kecepatan 1500 rpm (CiblancTM, China). Sebanyak $3 \mathrm{ml}$ campuran yang telah homogen kemudian diteteskan ke dalam kuvet kuarsa berukuran $10 \mathrm{~mm}$ dan digunakan untuk proses pengambilan spektra. Tabel 1 menunjukkan detail informasi sampel yang digunakan pada penelitian ini. Gambar 1 menunjukkan tampilan warna madu uniflora Acacia mangium dan madu multiflora yang digunakan pada penelitian ini. Kedua jenis madu tersebut sangat mirip warnanya sehingga sangat sulit membedakan keduanya secara visual menggunakan mata. 
Jurnal Teknologi Pertanian Vol. 22 No. 1 [April 2021] 25-34

Uji Keaslian Madu Lebah Hutan Apis dorsata dari Nektar Uniflora Acacia mangium [Suhandy dkk]

Tabel 1. Deskripsi sampel madu uniflora Acacia mangium dan multiflora yang digunakan pada penelitian

\begin{tabular}{lccc}
\hline Jenis Lebah & Jenis Madu & Asal Daerah & Jumlah Sampel \\
\hline Apis dorsata & Uniflora & Bandar Lampung & 50 \\
Apis dorsata & Multiflora & Lampung Selatan & 50 \\
\hline
\end{tabular}

Tabel 2. Matriks konfusi hasil klasifikasi sampel madu prediksi (40 sampel) menggunakan model LDA

\begin{tabular}{cccc}
\hline \multirow{2}{*}{ Sampel } & & \multicolumn{2}{c}{ Kelas Aktual } \\
\cline { 3 - 4 } & & Uniflora & Multiflora \\
\hline \multirow{2}{*}{ Kelas Prediksi } & Uniflora & 20 & 0 \\
& Multiflora & 0 & 20 \\
\hline
\end{tabular}
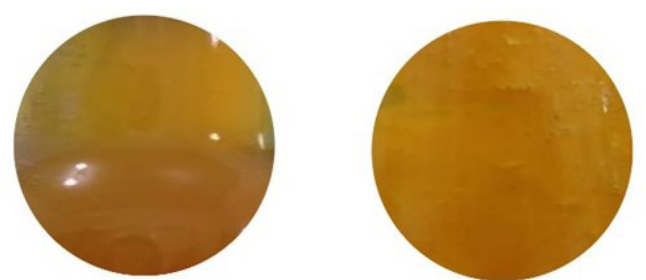

\section{Madu Uniflora Madu Multiflora}

Gambar 1. Tampilan sampel madu uniflora dan multiflora sebelum pengenceran

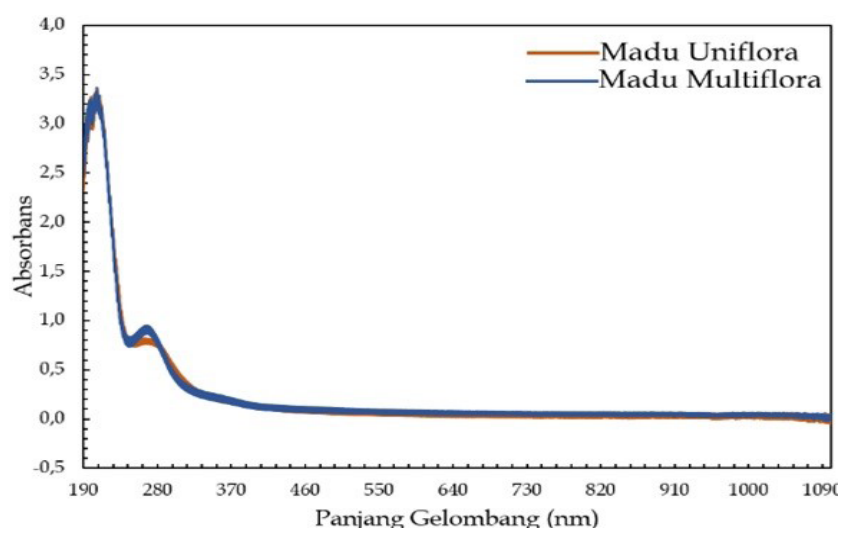

Gambar 2. Spektra original madu Apis dorsata uniflora Acacia mangium dan madu Apis dorsata multiflora di panjang gelombang $190-1100 \mathrm{~nm}$

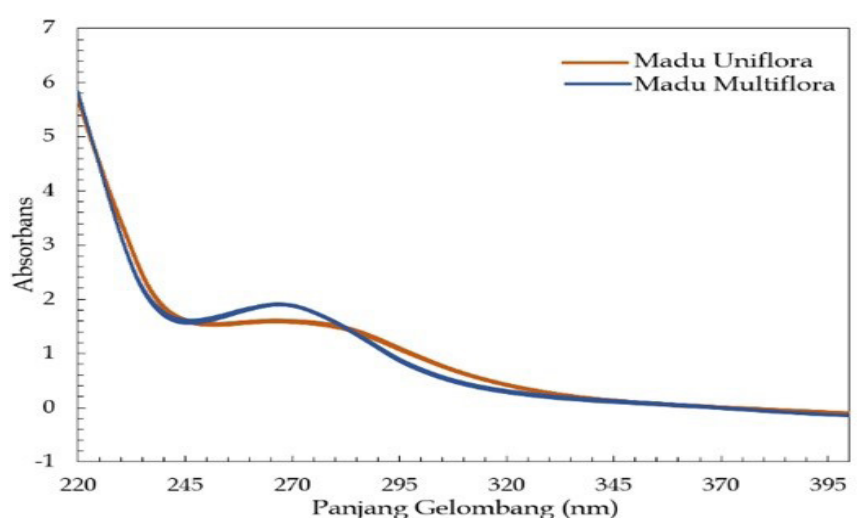

Gambar 3. Spektra modifikasi madu Apis dorsata uniflora Acacia mangium dan madu Apis dorsata multiflora di panjang gelombang $220-400 \mathrm{~nm}$ 


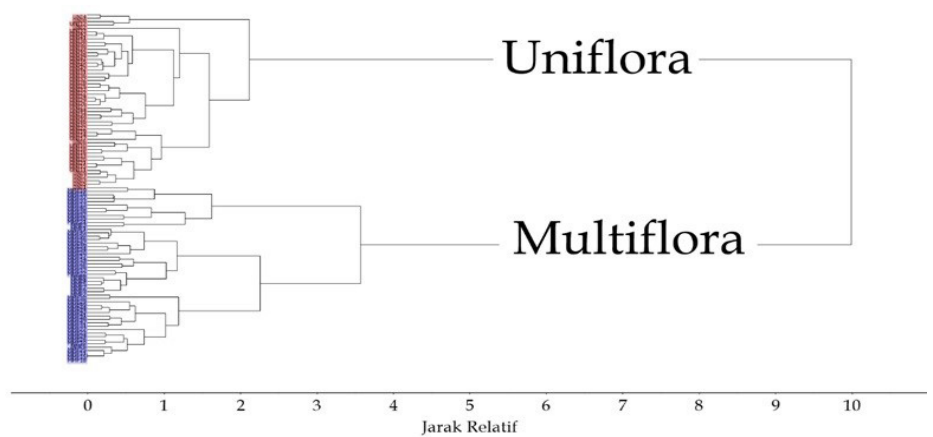

Gambar 4. Dendrogram hasil analisis kluster menggunakan metode complete linkage clustering untuk seluruh sampel pada spektra modifikasi di interval 220-400 nm

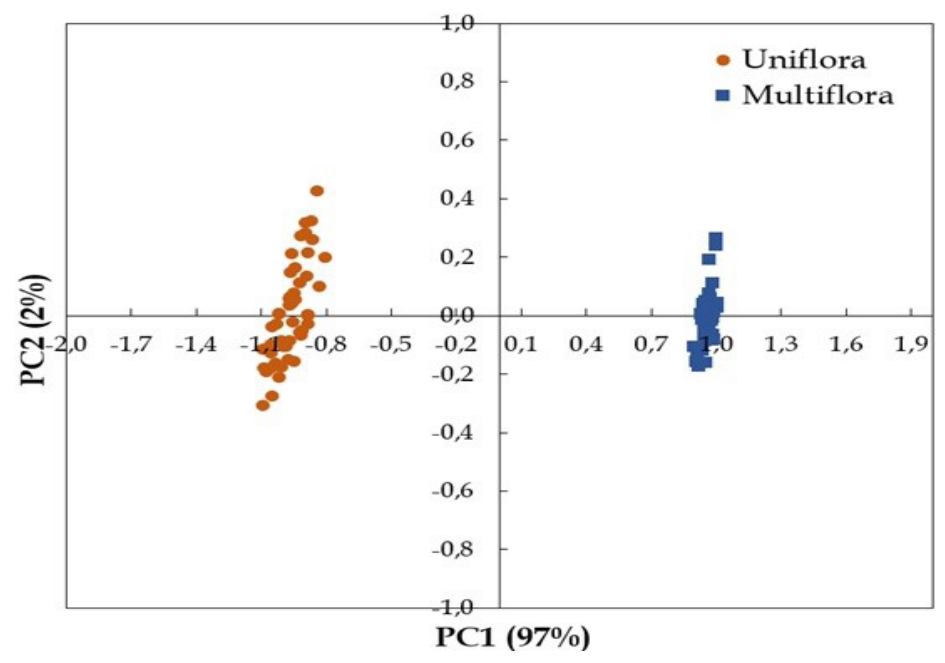

Gambar 5. Plot nilai skor PC1 dan PC2 hasil analisis PCA pada spektra modifikasi di interval $220-400 \mathrm{~nm}$

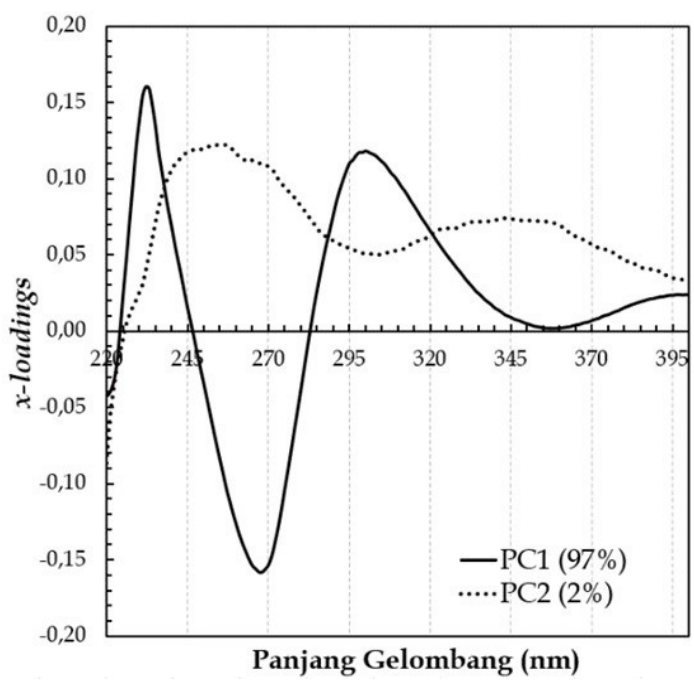

Gambar 6. Plot $x$-loadings versus panjang gelombang hasil analisis PCA pada spektra modifikasi di interval $220-400 \mathrm{~nm}$

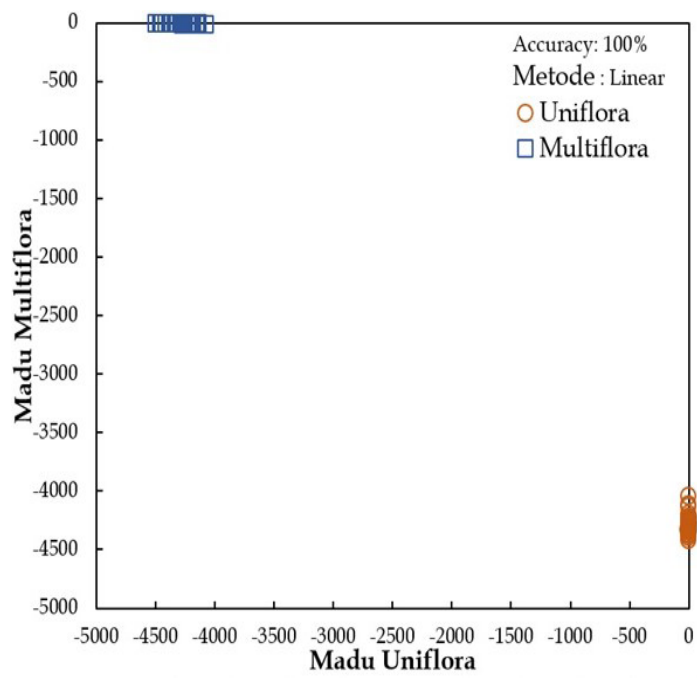

Gambar 7. Model klasifikasi LDA yang di bangun menggunakan lima variabel panjang gelombang dengan metode linear 


\section{Pengambilan Spektra Madu}

Spektra seluruh sampel madu dan referensi (air distilasi) di panjang gelombang 190-1100 nm (full spectrum) diakuisisi menggunakan spektrometer UV-visible (Genesys ${ }^{\mathrm{TM}}$ $10 S$ UV-Vis, Thermo Scientific, USA). Spektrometer ini merupakan salah satu spektrometer dual beam sehingga spektra sampel dan spektra referensi diukur secara bersamaan. Parameter yang digunakan untuk pengukuran spektra UV sampel madu dan referensi antara lain mode fast scanning, mode transmitansi, dan interval panjang gelombang sebesar $1 \mathrm{~nm}$. Data spektra dalam bentuk file ekstensi .csv disimpan dan diubah ke dalam format .xls. Data inilah yang kemudian diimpor ke dalam software the Unscrambler untuk analisis berikutnya.

\section{Kemometrika dan Software}

Untuk memperbaiki kualitas spektra dan meminimalkan noise pada spektra, dua metode pengolahan data spektra digunakan secara sekaligus untuk mengubah spektra original menjadi spektra modifikasi yaitu Savitzky-Golay smoothing dengan jumlah segmen sebesar 5 (SGS 5s) dan standard normal variate (SNV). Secara umum kedua metode pengolahan data spektra tersebut dapat meningkatkan nilai signal noise to ratio (SNR) spektra UV yang diukur (Suhandy et al., 2020). Dua metode klasifikasi tidak terbimbing (unsupervised classification) digunakan untuk klasterisasi sampel madu yaitu hierarchical cluster analysis (HCA) dan principal component analysis (PCA). HCA dihitung menggunakan algoritma complete linkage clustering dan jarak antar sampel dihitung menggunakan jarak Euclidean (Muhammad dan Azeredo, 2014). PCA dihitung menggunakan spektra modifikasi dengan algoritma NIPALS (nonlinear iterative partial least squares). PCA banyak digunakan untuk mengatasi data spektra yang memiliki kolinearitas tinggi (Muhammad dan Azeredo, 2014). Metode linear discrimination analysis (LDA) merupakan salah satu metode klasifikasi terbimbing (supervised classification) yang banyak digunakan pada klasifikasi madu (Aliaño-González et al., 2019; Stefas et al., 2020). Untuk menentukan variabel input pada metode LDA, nilai $x$-loading hasil PCA dibuatkan plotnya versus panjang gelombang (nm). Variabel dengan dengan nilai $x$-loading tinggi dipilih menjadi variabel input untuk menjalankan metode klasifikasi LDA. Akurasi klasifikasi
(AC) merupakan rasio antara jumlah sampel yang diklasifikasikan benar sesuai dengan dengan kelasnya (a) dan total sampel yang digunakan (n) dan dihitung menggunakan Persamaan (1).

$\mathrm{AC}(\%)=\mathrm{a} / \mathrm{n}$

Untuk menjalankan LDA, sampel dibagi secara acak ke dalam dua kelompok sampel yaitu sampel kalibrasi sebanyak 60 sampel dan sampel prediksi sebanyak 40 sampel. Software yang digunakan untuk melakukan perhitungan kemometrika termasuk modifikasi data spektra, HCA, PCA dan LDA adalah the Unscrambler 10.4 (Camo Software, Oslo, Norwegia).

\section{HASIL DAN PEMBAHASAN}

Gambar 2 merupakan spektra original seluruh sampel (100 sampel) untuk madu uniflora Acacia mangium dan madu multiflora pada panjang gelombang 190-1100 nm. Secara umum bentuk spektra yang diperoleh sejalan dengan hasil penelitian sebelumnya (Suhandy et al., 2020). Spektra dengan noise tinggi dengan nilai absorbans lebih dari 2 dapat dilihat di interval sekitar 190-220 nm. Ini dikenal juga sebagai high frequency noise. Spektra setelah panjang gelombang $400 \mathrm{~nm}$ memiliki intensitas absorbans yang sangat rendah (mendekati nol). Data spektra original ini biasanya kaya akan informasi yang tidak terkait langsung dengan komposisi kimia sampel seperti pengaruh hamburan cahaya dan perbedaan ukuran partikel sampel. Sebagian besar sumber cahaya atau lampu yang digunakan untuk spektroskopi ultraviolet saat ini juga memiliki intensitas yang lemah di sekitar panjang gelombang 190-220 nm. Pada penelitian ini misalnya digunakan lampu flash Xenon (Xe) sebagai sumber cahaya. Seperti ditunjukkan oleh Kim et al. (2009) dan Samotaev et al. (2015), lampu flash Xenon memiliki output relatif rendah di sekitar panjang gelombang 190-220 nm. Noise yang teridentifikasi di sekitar panjang gelombang 190-220 nm dengan nilai absorbans lebih dari 2 yang diperoleh pada penelitian ini juga sejalan dengan hasil beberapa penelitian sebelumnya. Misalnya, data spektra UV sampel kopi bubuk dari Brasil dan sampel kopi bubuk dari Indonesia (Souto et 
al., 2010; Suhandy dan Yulia, 2017a; Suhandy dan Yulia, 2017b). Dankowska et al. (2017) melaporkan spektrum serapan UV-Vis dari sampel kopi Arabika dan Robusta asli dan campurannya dalam kisaran 190-700 nm dan terlihat noise di sekitar panjang gelombang 190-250 nm. Diniz et al. (2016) melaporkan spektra absorbans sampel teh pada kisaran 190-800 nm di mana noise dengan absorbans sangat tinggi (lebih dari 2) teridentifikasi pada panjang gelombang 190-240 nm.

Spektra yang diperoleh menunjukkan terdapat perbedaan antara madu uniflora Acacia mangium dan madu multiflora. Madu multiflora memiliki nilai intensitas absorbans sedikit lebih besar dibandingkan dengan madu uniflora.Spektra modifikasi pada interval 220400 nm ditunjukkan di Gambar 3. Perbedaan spektra kedua jenis madu semakin jelas terlihat terutama di panjang gelombang sekitar 270 $\mathrm{nm}$ dan $300 \mathrm{~nm}$ yang dapat diduga berkorelasi dengan absorbans beberapa senyawa penting madu Acacia seperti senyawa phenolic acids dan flavonoids. Penelitian sebelumnya menunjukkan madu Acacia mangium dari lebah Apis mellifera memiliki konsentrasi senyawa phenolic acids dan senyawa flavonoids yang tinggi (Moniruzzaman et al., 2013). Dimitrova et al. (2007) menggunakan metode solid-pase extraction dan high-performance liquid chromatography dengan diode-array detection (DAD) pada panjang gelombang $220 \mathrm{~nm}$, $270 \mathrm{~nm}$, dan $340 \mathrm{~nm}$ berhasil mengidentifikasi beberapa senyawa phenolic acids dan flavonoids seperti benzoic, salicylic, dan aryl-alyphatic acids untuk beberapa jenis madu uniflora termasuk madu Acacia dari nektar bunga Robinia pseudoacacia L.

\section{Hasil Analisis Kluster}

Gambar 4 menunjukkan hasil analisis kluster menggunakan metode HCA dalam bentuk dendrogram yang disusun atas dasar kesamaan sampel (similarity). Di dalam sebuah dendrogram, sebuah sampel dengan nilai jarak relatif yang sama dihubungkan dengan sebuah garis mendatar. Pada Gambar 4 dapat dilihat bahwa dengan menggunakan jarak relatif sekitar 3,7 maka sampel madu dapat dikelompokkan ke dalam dua kluster berbeda yaitu kluster madu uniflora Acacia mangium dan kluster madu multiflora.

\section{Hasil PCA}

Plot nilai skor untuk dua PC pertama hasil analisis PCA ditunjukkan di Gambar 5. PCA dihitung untuk seluruh sampel (100 sampel) menggunakan spektra modifikasi di interval 220-400 $\mathrm{nm}$. Sampel madu terlihat terkelompokkan ke dalam dua kluster berbeda di sepanjang sumbu PC1 yang berhasil menjelaskan varian data awal sebesar $97 \%$. Kluster pertama yaitu madu uniflora Acacia mangium terletak di PC1 negatif $(\mathrm{PC} 1<0)$ dan kluster kedua yaitu madu multiflora terletak di PC1 positif (PC1>0).

Untuk mencari variabel yang paling berpengaruh terhadap proses pemisahan sampel seperti yang ditunjukkan di Gambar 5, maka plot $x$-loading versus panjang gelombang hasil analisis PCA dibuat dan ditunjukkan di Gambar 6. Panjang gelombang dengan nilai $x$-loadings tinggi (baik positif maupun negatif) menunjukkan panjang gelombang tersebut semakin kontributif terhadap proses pemisahan sampel. Gambar 6 menunjukkan lima panjang gelombang memiliki nilai $x$-loadings tinggi yaitu panjang gelombang $233 \mathrm{~nm}, 258 \mathrm{~nm}, 268 \mathrm{~nm}, 300 \mathrm{~nm}$ dan $350 \mathrm{~nm}$. Dimitrova et al. (2007) menyatakan bahwa panjang gelombang $270 \mathrm{~nm}$ dan 300 nm memiliki korelasi dengan absorbans senyawa penting pada beberapa madu uniflora termasuk madu uniflora Acacia (Robinia pseudoacacia L.) seperti senyawa benzoic, salicylic dan aryl-alyphatic acids. Khususnya untuk senyawa benzoic acid merupakan salah satu senyawa phenolic acids yang juga banyak ditemukan pada madu uniflora Acacia mangium dari lebah Apis mellifera seperti yang dilaporkan dan dirangkum oleh beberapa periset sebelumnya (Moniruzzaman et al., 2013; Pyrzynska dan Biesaga, 2009). Senyawa ini merupakan salah satu senyawa antioksidan dan berperan penting untuk mendukung madu sebagai salah satu sumber pangan dengan manfaat medis.

\section{Klasifikasi LDA}

Klasifikasi terbimbing untuk mengklasifikasikan madu ke dalam 2 kelas yaitu kelas madu uniflora Acacia mangium dan kelas madu multiflora. Ini dilakukan dengan menggunakan metode LDA dengan melibatkan sampel kalibrasi (60 sampel) dan metode linear. Variabel inputnya digunakan lima panjang gelombang yang memiliki nilai $x$ loadings tinggi yaitu panjang gelombang 233 nm, $258 \mathrm{~nm}, 268 \mathrm{~nm}, 300 \mathrm{~nm}$ dan $350 \mathrm{~nm}$. Hasil pengembangan model klasifikasi LDA ditunjukkan di Gambar 7.

Model ini menunjukkan sumbu mendatar sebagai kelas madu uniflora Acacia 
mangium dan sumbu vertikal sebagai kelas madu multiflora. Model dikatakan semakin baik jika sampel terletak semakin dekat ke nilai 0 untuk kelas yang bersesuaian. Seperti terlihat di Gambar 7, seluruh sampel madu uniflora Acacia mangium terletak di nilai 0 di sepanjang sumbu mendatar (kelas madu uniflora). Hal yang sama teridentifikasi untuk sampel madu multiflora yang seluruh sampelnya terletak di nilai 0 di sepanjang sumbu vertikal (kelas madu multiflora) yang menghasilkan akurasi model klasifikasi sebesar $100 \%$.

Untuk mengevaluasi kinerja model klasifikasi LDA yang telah dibangun maka dilakukan klasifikasi terhadap sampel prediksi (40 sampel). Sampel ini berbeda dengan sampel yang digunakan pada proses pengembangan model LDA. Hasilnya ditunjukkan dalam bentuk matriks konfusi seperti di Tabel 2. Seluruh sampel prediksi berhasil diklasifikasikan secara benar sesuai dengan kelasnya yang menghasilkan akurasi klasifikasi sebesar $100 \%$. Efektivitas penggunaan metode HCA, PCA, dan LDA untuk klasifikasi tidak terbimbing dan terbimbing khususnya pada madu sudah ditunjukkan oleh periset sebelumnya. Ferreiro-González et al. (2018), menggunakan metode HCA, PCA, dan LDA untuk proses diskriminasi madu asli Granada dan madu yang sudah dicampur sirup jagung dengan akurasi metode LDA mencapai 100\%. Giordano et al. (2019) menggunakan metode LDA dan infrared spectroscopy untuk mengklasifikasikan 4 jenis madu uniflora dengan akurasi sebesar 75-100\%.

\section{SIMPULAN}

Sebagai salah satu madu premium, madu uniflora Acacia mangium menjadi salah satu target pemalsuan salah satunya dengan menggunakan madu multiflora yang memiliki warna madu yang mirip sehingga keduanya sulit dibedakan secara visual. Penelitian ini berhasil menunjukkan potensi aplikasi metode analisis spektroskopi ultraviolet dan kemometrika untuk mengklasifikasikan madu uniflora Acacia mangium (yang lebih mahal) dan madu multiflora. Metode klasifikasi terbimbing LDA dengan hanya melibatkan 5 variabel panjang gelombang menghasilkan akurasi klasifikasi sebesar $100 \%$ untuk kalibrasi dan prediksi. Secara praktis, pengukuran spektra hanya di 5 panjang gelombang membuat proses hilirisasi teknologi spektroskopi ultraviolet untuk uji keaslian madu uniflora Acacia mangium menjadi lebih mudah dan memungkinkan dengan proses pengukuran spektra yang lebih cepat.

\section{UCAPAN TERIMA KASIH}

Penulis mengucapkan terima kasih kepada Kementerian Riset dan Teknologi/ Badan Riset dan Inovasi Nasional (KEMENRISTEK/BRIN) atas bantuan pendanaan melalui hibah Riset Terapan 2020-2022.

\section{KONFLIK KEPENTINGAN}

Penulis menyatakan tidak ada konflik kepentingan dalam penulisan naskah karya ilmiah ini.

\section{DAFTAR PUSTAKA}

Aliaño-González, M, -J., Ferreiro-González, -M., Espada-Bellido, -E., Palma, -M., Barbero, -G, -F., 2019. A screening method based on Visible-NIR spectroscopy for the identification and quantification of different adulterants in high-quality honey. Talanta. 203, 235-241. https://doi.org/10.1016/j. talanta.2019.05.067

Andrarde, P., -B., Amaral, M, -T., Isabel, -P., Carvalho, J, C, M, -F., Seabra, R, -M., da Cunha, A, -P., 1999. Physicochemical attributes and pollen spectrum of Portuguese heather honeys. Food Chemistry. 66(4), 503-510. https://doi. org/10.1016/S0308-8146(99)00100-4

Anjos, -O., Iglesias, -C., Peres, -F., Martínez, -J., García, -A., Taboada, -J., 2015. neural networks applied to discriminate botanical origin of honeys. Food Chemistry. 175, 128-136. https://doi. org/10.1016/j.foodchem.2014.11.121

Corvucci, -F., Nobili, -L., Melucci, -D., Grillenzoni, F, -V., 2015. The discrimination of honey origin using melissopalynology and Raman spectroscopy techniques coupled with multivariate analysis. Food Chemistry. 169, 297-304. https://doi.org/10.1016/j.foodchem.2014.07.122 
Da Silva, P, -M., Gauche, -C., Gonzaga, L, -V., Costa, A, C, -O., Fett, -R., 2016. Honey: Chemical composition, stability and authenticity. Food Chemistry. 196, 309-323. https://doi.org/10.1016/j. foodchem.2015.09.051

Dankowska, -A., Domagała, -A., Kowalewski, -W., 2017. Quantification of coffea arabica and coffea canephora var. robusta concentration in blends by means of synchronous fluorescence and UV-Vis spectroscopies. Talanta. 172, 215-220. https:// doi.org/10.1016/j.talanta.2017.05.036

Dimitrova, -B., Gevrenova, -R., Anklam, -E., 2007. Analysis of phenolic acids in honeys of different floral origin by solid-phase extraction and high-performance liquid chromatography. Phytochemical Analysis. 18(1), 24-32. https:/ / doi.org/10.1002/pca.948

Diniz, P, H, G, -D., Barbosa, M, -F., De Melo Milanez, K, D, -T., Pistonesi, M, -F., De Araújo, M, C, -U., 2016. Using UV-Vis spectroscopy for simultaneous geographical and varietal classification of tea infusions simulating a home-made tea cup. Food Chemistry. 192, 374-379. https://doi.org/10.1016/j.foodchem.2015.07.022

Ferreiro-González, -M., Espada-Bellido, -E., Guillén-Cueto, -L., Palma, -M., Barroso, C, -G., Barbero, G, -F., 2018. Rapid quantification of honey adulteration by visible-near infrared spectroscopy combined with chemometrics. Talanta. 188, 288-292. https:/ / doi. org/10.1016/j.talanta.2018.05.095

Frausto-Reyes, -C., Casillas-Peñuelas, -R., Quintanar-Stephano, J, -L., MacíasLópez, -E., Bujdud-Pérez, J, -M., Medina-Ramírez, -I., 2017. Spectroscopic study of honey from Apis mellifera from different regions in Mexico. Spectrochimica Acta Part A: Molecular and Biomolecular Spectroscopy. 178, 212-217. https://doi.org/10.1016/j. saa.2017.02.009

Giordano, -A., Retamal, -M., Fuentes, -E., Ascar, -L., Velásquez, -P., Rodríguez, -K., Montenegro, -G., 2019. Rapid scanning of the origin and antioxidant potential of chilean native honey through infrared spectroscopy and chemometrics. Food Analytical Methods. 12, 1511-1519. https:/ / doi.org/10.1007/s12161-01901473-z
Hennessy, -S., Downey, -G., O'donnell, C, -P., 2010. Attempted confirmation of the provenance of corsican PDO honey using FT-IR spectroscopy and multivariate data analysis. Journal of Agricultural and Food Chemistry. 58, 9401-9406. https://doi.org/10.1021/jf101500n

Kasprzyk, -I., Depciuch, -J., Grabek-Lejko, -D., Parlinska-Wojtan, -M., 2018. FTIRATR spectroscopy of pollen and honey as a tool for unifloral honey authentication. The case study of rape honey. Food Control. 84, 33-40. https://doi. org/10.1016/j.foodcont.2017.07.015

Kim, H, -S., Dhage, S, -R., Shim, D, -E., Hahn, $\mathrm{H},-\mathrm{T} ., 2009$. Intense pulsed light sintering of copper nanoink for printed electronics. Applied Physic A Material Science and Processing. 97, 791-798. https:/ / doi. org/10.1007/s00339-009-5360-6

Kuballa, -T., Brunner, T, -S., Thongpanchang, -T., Walch, S, -G., Lachenmeier, D, -W., 2018. Application of NMR for authentication of honey, beer and spices. Current Opinion in Food Science. 19, 57-62. https://doi.org/10.1016/j. cofs.2018.01.007

Kuropatnicki, A, -K., Kłósek, -M., Kucharzewski, -M., 2018. Honey as medicine: historical perspectives. Journal of Apicultural Research. 57, 113-118. https://doi.org/1 0.1080/00218839.2017.1411182

Lenhardt, -L., Zeković, -I., Dramićanin, -T., Tešić, -Z., Milojković-Opsenica,-D., Dramićanin, M, -D., 2014. Authentication of the botanical origin of unifloral honey by infrared spectroscopy coupled with support vector machine algorithm. Physica Scripta. T162. https://doi.org/10.1088/00318949/2014/T162/014042

Liu, -W., Zhang, -Y., Yang, -S., Han, -D., 2018. Terahertz time-domain attenuated total reflection spectroscopy applied to the rapid discrimination of the botanical origin of honeys. Spectrochimica Acta Part A: Molecular and Biomolecular Spectroscopy. 196, 123-130. https:// doi.org/10.1016/j.saa.2018.02.009

Mădaş, M, -N., Mărghitaş, L, -A., Dezmirean, D, -S., Bobiş, -O., Abbas, -O., Danthine, -S., Francis, -F., Haubruge, -E., Nguyen, B, -K., 2019. Labeling regulations and quality control of honey origin: A review. Food Reviews International. 36, 215-240. https://doi.org/10.1080/875 59129.2019.1636063 
Martins, R, -C., Lopes, V, -V., Valentão, -P., Carvalho, J, C, M, -F., Isabel, -P., Amaral, M, -T., Batista, M, -T., Andrade, P, -B., Silva, B, -M., 2008. Relevant principal component analysis applied to the characterisation of Portuguese heather honey. Natural Product Research. 22, 1560-1582. https://doi. org/10.1080/14786410701825004

Mehretie, -S., Al Riza, D, -F., Yoshito, -S., Kondo, -N., 2018. Classification of raw Ethiopian honeys using front face fluorescence spectra with multivariate analysis. Food Control. 84, 83-88. https://doi.org/10.1016/j.foodcont.2017.07.024

Mondragón-Cortez, -P., Ulloa, J, -A., RosasUlloa, -P., Rodríguez-Rodríguez, -R., Resendiz Vázquezc, J, -A., 2013. Physicochemical characterization of honey from the West region of México. CyTA - Journal of Food. 11, 7-13. https:/ / doi. org/10.1080/19476337.2012.673175

Moniruzzaman, -M., Sulaiman, S, -A., Azlan, S, A, -M., Gan, S, -H., 2013. Two-year variations of phenolics, flavonoids and antioxidant contents in acacia honey. Molecules. 18, 14694-14710. https:// doi.org/10.3390/molecules181214694

Muhammad, -A., Azeredo, R, B, D, -V., 2014. ${ }^{1} \mathrm{H}$ NMR spectroscopy and low-field relaxometry for predicting viscosity and API gravity of Brazilian crude oils - A comparative study. Fuel. 130, 126-134. https://doi.org/10.1016/j. fuel.2014.04.026

Oddo, L, -P., Piro, -R., 2004. Main European unifloral honeys: descriptive sheets. Apidologie. 35, S38-S81. https://doi. org/10.1051/apido:2004049

Piana, M, -L., Oddo, L, -P., Bentabol, -A., Bruneau, -E., Bogdanov, -S., Declerck, -C., 2004. Sensory analysis applied to honey: state of the art. Apidologie. 35, S26-S37. https://doi.org/10.1051/apido:2004048

Pyrzynska, -K., Biesaga, -M., 2009. Analysis of phenolic acids and flavonoids in honey. TrAC Trends in Analytical Chemistry. 28, 893-902. https://doi. org/10.1016/j.trac.2009.03.015

Samotaev, -N., Vasilyev, -V., Malkin, -E., Gromov, -E., Belyakov, -V., Golovin, -A., Pershenkov, -V., Ivanov, -I., Shal- taeva, -Y., Matusko, -M., 2015. System for synchronous detection trace of explosives and drags substances on human fingers. Procedia Engineering. 120, 1050-1053. https://doi.org/10.1016/j. proeng.2015.08.722

Souto, U, T, C, -P., Pontes, M, J, -C., Silva, E, -C., Galvão, R, K, -H., Araújo, M, C, -U., Sanches, F, A, -C., Cunha, F, A, -S., Oliveira, M, S, -R., 2010. UV-Vis spectrometric classification of coffees by SPA-LDA. Food Chemistry. 119, 368-371. https://doi.org/10.1016/j. foodchem.2009.05.078

Stefas, -D., Gyftokostas, -N., Couris, -S., 2020. Laser induced breakdown spectroscopy for elemental analysis and discrimination of honey samples. Spectrochimica Acta Part B: Atomic Spectroscopy. 172, 105969. https://doi.org/10.1016/j. sab.2020.105969

Suhandy, -D., Yulia, -M., 2017a. The use of partial least square regression and spectral data in UV-Visible region for quantification of adulteration in Indonesian palm civet coffee. International Journal of Food Science. 2017, 1-7. https://doi.org/10.1155/2017/6274178

Suhandy, -D., Yulia, -M., 2017b. Peaberry coffee discrimination using UV-visible spectroscopy combined with SIMCA and PLS-DA. International Journal of Food Properties. 20, S331-S339. https://doi.or g/10.1080/10942912.2017.1296861

Suhandy, -D., Yulia, -M., Kusumiyati., 2020. Klasifikasi madu berdasarkan jenis lebah (Apis dorsata versus Apis mellifera) menggunakan spektroskopi ultraviolet dan kemometrika. Jurnal Ilmu Pertanian Indonesia. 25, 564-573. https://doi.org/10.18343/jipi.25.4.564

Tewari, -J., Irudayaraj, -J., 2004. Quantification of saccharides in multiple floral honeys using fourier transform infrared microattenuated total reflectance spectroscopy. Journal of Agricultural and Food Chemistry. 52, 3237-3243. https://doi.org/10.1021/jf035176+

Von Der Ohe, -W., Oddo, L, -P., Piana, M, -L., Morlot, -M., Martin, -P., 2004. Harmonized methods of melissopalynology. Apidologie. 35, S18-S25. https://doi. org/10.1051/apido:2004050 